\title{
Eleven years experience with the use of Contegra ${ }^{\circledR}$ Zeid Makahleh*, FRCS C-Th \\ *Queen Alia Heart Institute at King Hussein Medical Center, Amman, Jordan.
}

\section{Objective:}

The implantation of the Bovine Jugular Vein (Contegra) in the repair of many congenital heart defects (CHD) had gained a worldwide acceptance. We report our experience in using it over eleven years.

\section{Methods:}

During the period from February 2000- December 2011, we implanted the Contegra in 268 patients with different congenital heart defects at the position ventricle-Pulmonary artery (RV/LV-PA).

There were 178 males and 90 females in an age ranging between 2 months- 33 years mean of $5.6 \mathrm{yrs}$. Echocardiography was performed postoperatively at 3days, 3months, 6months then every year looking for pressure gradient (PG) across the valve, regurgitation and calcification.

The primary endpoints of operative mortality and morbidity and secondary endpoints of follow-up haemodynamic performance including severe stenosis, regurgitation and need for reintervention are presented.

\section{Results:}

The follow up of patients were 100\% in $1 \mathrm{yr}$, 98\% in $2 \mathrm{yrs}$; $82 \%$ in $3 \mathrm{yrs}$ and $57 \%$ in $4 \mathrm{yrs}, 40 \%$ in $5 \mathrm{yrs}, 35 \%$ in $6 \mathrm{yrs}, 20 \%$ continued to show up from year 7 to year 11 .

The performance of the conduit was as follow: Unchanged pressure gradient (PG) or $<15 \mathrm{mmHg}$ over $2 \mathrm{yrs}$ in $98 \%$, PG $15-25 \mathrm{mmHg}$ over $3 \mathrm{yrs}$ in $25 \%$, PG $25-35 \mathrm{mmHg}$ over $4 \mathrm{yrs}$ in $18 \%$, PG $35-$ $45 \mathrm{mmHg}$ over $5 \mathrm{yrs}$ in $14 \%$, and by the end of $11 \mathrm{yrs} 10 \%$ of pts had PG >55 mmHg, and were scheduled for redo surgery. The rest of the patients were having minor changes in the pressure gradients over variable periods of follow up.

The younger the child at the time of implantation, the higher the chance to develop pressure gradient over the conduit over years.

There were no conduit related adverse events, there were 32 deaths; 12 early deaths (4.5\%), late 20 deaths, not related to conduit implantation.

Operative morbidity was $11.2 \%$.

There were mild regurgitation at the valve in 32 cases $(12 \%)$; moderate regurgitation in 9 cases (3.4\%) and severe regurgitation in 6 cases $(2.2 \%)$ at variable periods of follow up, calcifications were detected by X-ray and sonography in 37 cases $(13.8 \%)$

Reintervention by redo surgical procedure in 33 cases (12.3\%)

\section{Conclusion}

The Contegra conduit is $\mathrm{s}$ a reliable extra-cardiac conduit for primary and redo- RVOT reconstruction over eleven years of follow up. 
Keywords: DORV (double outlet right ventricle), PS (pulmonary stenosis), TOF (Tetrology of Fallot) PA (pulmonary atresia), TGV (transposition of great vessels), VSD (Ventricular Septal Defect), RVOT (right ventricular outflow tract), PG (pressure gradient)

Correspondence to Zeid Makahleh, FRCS CTh, Queen Alia Heart Institute at King Hussein Medical Center, Amman, Jordan, P.O.Box: 2699 / 11953 Amman, Jordan

E-mail: zmakahleh@yahoo.com

Mobile: +962795515001

\section{Introduction}

The surgical repair of many congenital heart defects requiring the implantation of valved conduit between the right ventricle (RV) and pulmonary artery (PA) is still a challenging issue in terms of using the ideal valved conduit that has the growth potential, non-thrombogenic, and functional infinity, wide range of sizes and 'off-the-shelf' availability.

Many types have been used including prosthetic valve conduit, autogenous tissue reconstruction (Danielson et al., 1987), Ovine pulmonary valved conduit (Brawn, 1995), Equine pulmonary valve conduit (Imai et al., 1995) and Homograft.

The gold standard conduit for the reconstruction of right ventricular out flow tract tended to be the pulmonary homograft (Imai et al., 1995). However, these conduits are scarce especially in small sizes and $75 \%$ of them have to be replaced within five years because of the increasing insufficiency and calcifications (Daenen and Gewilling, 1997, Forbess et al.2001, Tweddell et al. 2000, and Bielefeld et al.2001).

Porcine xenografts perform worse than homografts with respect to all durability parameters such as early calcification, stenosis of the valve, incompetence, pannus and graft tissue stiffness (Stark, 1998, Lewine et al., 2001 and Homann et al.2000).

The Contegra $^{\circledR}$ conduit, a totally integrated valved conduit, consists of a bovine jugular vein with a naturally integrated valve in it. Only venous valves consisting of three leaflets with natural sinuses are made available for clinical purposes. Abundant material on both sides of the valve allows enhanced implantation techniques. The Contegra $^{\circledR}$ conduit is treated by a buffered low pressure glutaraldehyde fixation. No additional anticalcification treatment is used. The conduits are available in sizes from 12 to $22 \mathrm{~mm}$. They are also available with rings as reinforcement. We used only the ring-less conduits because we consider pliability as one of the big advantages of this material.

We started to use the $\left(\right.$ Contegra $^{\circledR}$, Medtronic,Inc. Menneoplis, Minn, USA) December 1999 in RV/LV - PA position, so we report our experience in the use of it over eleven years.

\section{Methods:}

Over the period from February 2000 to December 2011, we implanted the Contegra in 268 patients with different congenital heart defects at the position of ventricle-Pulmonary artery (RV/LV-PA).

Contegra; valved bovine internal jugular vein conduit (Medtronic Inc., MN, USA) has been 


\section{Zeid Makahleh}

advocated for its 'off-the-shelf' availability in sizes ranging from 12 to $22 \mathrm{~mm}$.

Echocardiography was performed postoperatively at 3 days, 3 months, 6 months then every year looking for pressure gradient across the valve, regurgitation and calcification.

The procedure of implantation of the Contegra between the right ventricle and the pulmonary artery was as follow done by two pediatric surgeons:

1. Choose the appropriate size of the valved conduit according to the age, weight and surface area of the patient .Introduce Hegar of the same size at the site of implantation to get a general idea about the relation of the conduit to the surrounding structures and to see if the space is enough to accommodate the size of the conduit without any compromise (figure 1)

2. Open the main pulmonary artery or the junction of the pulmonary arteries transversely till it is slightly larger than the distal size of the used contegra to prevent plication during suturing that is transferred later into stenosis at the site of anastomosis (you might take part of the contegra to make angioplasty to either/or both PA's)

3. The distal end of the conduit is cut in a way to adjust its position in relation to the ventriculotomy

4. Reduce the length of the conduit distal to the valve as much as possible to prevent its compression between the RV \& the inner surface of the sternum.

5. Start the distal anastomosis first with the posterior raw while applying the pump suction outside the graft till it is done, and then inserts the pump sucker very gently within the conduit through the anastomosis site to complete the anterior raw (figure 2).

6. Release all the stay sutures and remove the cross clamp to allow filling of the distal portion (a bulb syringe can be used to insufflate normal saline into the proximal part to fill it up) to determine the final length \& position of the graft in relation to the ventriculotomy (Figure 3).

7. Mark the inferior surface of the conduit at the edge of proximal part of ventriculotomy, incise the inferior surface of the conduit longitudinally from the free edge to the marked point where the anastomosis starts.

8. While running the sutures around the ventriculotomy, tapering of the proximal part is determined to fit with the ventriculotomy site ( you may need to fill the right ventricle by pinching the venous line to have better look for the final shape of the proximal anastomosis The primary endpoints of operative mortality and morbidity, and secondary endpoints of follow-up haemodynamic performance including severe stenosis, regurgitation and need for re-intervention are presented.

\section{Results:}

We implanted the Contegra in 268 patients with different congenital heart defects at the position of ventricle-Pulmonary artery (RV/LV-PA).

There were 178 males and 90 females in an age ranging between 2 months- 33 years mean of 5.6years. Demographic distribution of the cases is shown in Table 1. 


\begin{tabular}{||c||c|c|c|c||}
\hline \hline Preoperative diagnosis & age & $\begin{array}{c}\text { Weight } \\
\mathbf{k g}\end{array}$ & $\begin{array}{c}\text { Number of } \\
\mathbf{p t}\end{array}$ & Size of the contegra \\
\hline \hline Truncus Arterious(TA) & $3-6$ mon & $3.3-4.1$ & 52 & $12 \mathrm{~mm}$ \\
\hline DORV/TOF, VSD, PS & $2-12$ yrs & $8-26$ & 53 & $14-18 \mathrm{~mm}$ \\
\hline Redo - RV to PA conduit & $8.0-33 \mathrm{yrs}$ & $17-70$ & 105 & $18-22 \mathrm{~mm}$ \\
\hline PS/P. atresia & $1-6 \mathrm{yrs}$ & $10-17$ & 20 & $14-18 \mathrm{~mm}$ \\
\hline L/D TGV,VSD, PS & $4 \mathrm{mon}-11 \mathrm{yrs}$ & $4-22$ & 25 & $12-20 \mathrm{~mm}$ \\
\hline TOF absent pulm. valve & $14 \mathrm{mon}-4$ yrs & $6-14$ & 13 & $12-18 \mathrm{~mm}$ \\
\hline
\end{tabular}

Table 1. Demographic distribution of the cases. DORV: Double outlet left ventricle. TOF: Tetralogy of Fallot. VSD: Ventricular Septal defect. PS: Pulmonary stenosis. RV: Right ventricle. TGV: Transposition of great vessels

The preoperative diagnosis includes:

Truncus Arteriosus 52 cases(19.4\%), DORV,PS / TOF 53cases(19.8\%), PSPA 20 cases(7.5\%), Re-do RV-PA 105 cases(39.2\%), L / D TGV/VSD,PS 25 cases (9.3\%), TOF absent pulmonary valve 13 cases(4.9\%)

The sizes of implanted Contegra were ;12 $\mathrm{mm}(58$ cases), $14 \mathrm{~mm}(29$ cases $), 16 \mathrm{~mm}(25$ cases), $18 \mathrm{~mm} \quad$ (36 cases), $20 \mathrm{~mm} \quad(25$ cases), $22 \mathrm{~mm}$ ( 95 cases)

The follow up of patients were $100 \%$ in $1 \mathrm{yr}, 98 \%$ in $2 \mathrm{yrs} ; 82 \%$ in $3 \mathrm{yrs}$ and $57 \%$ in 4 yrs, $40 \%$ in $5 \mathrm{yrs}, 35 \%$ in 6 yrs, $20 \%$ continued to show up from year 7 to year 11 . The performance of the conduit was as follow:

- Unchanged pressure gradient (PG) or $<15$ mmHg over 2 yrs in $98 \%$,

- PG $15-25 \mathrm{mmHg}$ over $3 \mathrm{yrs}$ in $25 \%$,

- PG 25 -35mmHg over 4yrs in 18\%,

- $\mathrm{PG} 35-45 \mathrm{mmHg}$ over $5 \mathrm{yrs}$ in $14 \%$

- And by the end of 11 yrs $10 \%$ of pts had PG $>55 \mathrm{mmHg}$ and were scheduled for redo surgery.
The rest of the patients were having minor changes in the pressure gradients over variable periods of follow up.

The younger the child at the time of implantation, the higher the chance to develop pressure gradient over the conduit over years.

There were mild regurgitation at the valve in 32 cases (12\%), moderate regurgitation in 9 cases $(3.4 \%)$ and severe regurgitation in 6 cases $(2.2 \%)$ at variable periods of follow up, calcifications were detected by X-ray and sonography in 37 cases (13.8\%), however, its degree did not increase over time as frequently observed in homograft conduits (Baskett et al., 1996 and Chiu Chan et al., 1994).

Up to now, there were no device-related adverse events.

Cumulative operative morbidity was $11.2 \%$; thirty patients suffered one of the complications listed in (table2). 


\begin{tabular}{||l|c||}
\hline \multicolumn{1}{|c|}{ Type } & Number \\
\hline \hline Re-opening for bleeding & 8 \\
\hline Sepsis & 4 \\
\hline Respiratory & 9 \\
\hline Neurological & 4 \\
\hline Renal & 1 \\
\hline Cardiac & 4 \\
\hline
\end{tabular}

Table 2 Peri-operative complications

We had to replace the Contegra with another one in 33 cases (12.3\%); in 26 cases for the need to upgrade the size of the contegra, in 6 cases because of severe regurgitation, and in one case because of endocarditis.

There were no conduit related adverse events, there were 32 deaths; early (within 30 days after the surgery) 12deaths (4.5\%), late 20 deaths, not related to conduit implantation.

\section{Discussion:}

In this study, we report our experience with the Contegra ${ }^{\circledR}$ conduit implanted in pediatric and grown-up patients requiring RVOT reconstruction in a wide range of complex cardiovascular malformations particularly in early childhood. It is generally accepted that valved conduits should be used as the first choice (Bove et al., 1983). Homografts are considered as gold standard (di Carlo et al., 1984 and Kay and Ross, 1985). However, homografts often show early degeneration and calcification, particularly in very young patients (Hawkins et al., 1992). Primarily due to shortage of small homografts and after disappointing experiences with porcine aortic xenografts (Lewine et al., 2001),

we started to implant Contegra ${ }^{\circledR}$ conduits in December 1999. The Contegra ${ }^{\circledR}$ conduit consists of an exceptionally pliable tissue and therefore offers unique qualities for surgical handling. The abundant tissue at both sides of the valve allows enhanced implantation techniques. Suturing is rather easy and the material is resistant to suture tear. Further foreign material for the proximal anastomosis is not necessary. It has to be noted that the Contegra $^{\circledR}$ conduit contains a high profile valve. The bovine jugular venous valve leaflets are longer in direction of the conduit tube than homo- or xenograft valves. As a result, particularly in infants, the valve often requires almost the whole conduit length from the proximal to the distal anastomosis and has therefore to be positioned as distal as possible. The Contegra ${ }^{\circledR}$ conduit allows the surgeon easily to implant the graft leftwards to avoid the risk of damaging the conduit during a later sternotomy.

After analyzing the data collected we gathered the patients into different groups 
(table 1) that have common factors, to fix the variables and look at the performance of the Contegra separately, these variables were; the age/size of the patient at the time of implantation of the conduit, the size of the pulmonary arteries, pulmonary artery pressure and its reversibility after the repair, run-off in distal pulmonary vasculature, presence of collaterals and finally the position of Contegra being between the RV/LV to PA.

So we found that Truncus patients $(n=52)$ are the youngest group ranging between 2 mon -6 mon, they have relatively large pulmonary arteries with reversible PAP(pulmonary artery pressure), they did well postoperatively but over time they overgrow the size of the Contegra, and they tend to develop progressive gradient across the valve after $3 y r s$ of follow up, and because the size of the contegra we use in the initial repair is mainly size $12 \mathrm{~mm}$ ( just appropriate to fit in the small sized mediastinum) and we find it difficult to upgrade it to size $14 \mathrm{~mm}$ intraoperatively, there were three deaths among this group not related to the device.

Next group was the DORV/PS and TOF $(n=53)$ whose age ranging from 2 $12 \mathrm{yrs}$, in $30 \%$ of them they have left pulmonary artery (LPA) stenosis, that caused progressive PG over the LPA, the remainder conduits had no progressive PG over 5yrs since the majority had their Contegra upgraded at the time of implantation, the sizes used among this group were $14-18 \mathrm{~mm}$ and there were two death among them.

The redo- RV to PA are the largest group $(n=105)$ whose age ranging between 8 -
$33 \mathrm{yrs}$ mean of $16.5 \mathrm{yrs}$, those had previously RVOT patch but no conduits, they didn't show progressive PG over 11years of follow up, in the majority probably because the size of the Contegra implanted were almost the adult size $18-22 \mathrm{~mm}, 80 \%$ of implantation were done without cross clamp, the remainder were implanted on cross clamp due to the presence of residual VSD. The performance of the conduit was excellent even in the adult age group whose weight is above $60 \mathrm{Kg}$.

In the $\mathrm{L} / \mathrm{D} \mathrm{TGV}, \mathrm{VSD}$, PS group $(n=25)$ were between 6mon - 9yrs, the construction of the LV/RV - PA needed more engineering than the other groups and the conduit takes longer course underneath the sternum but surprisingly the conduits had less progressive PG over 4 yrs of follow up, in addition this group had higher incidence of complete AV block that needed permanent pacemaker but didn't affect the performance of the Contegra, there were three early deaths and two late deaths in this group.

The pulmonary atresia group $(n=20)$ had the highest mortality ( 4 patients died and 2 patients had their follow up lost), in 50\% of this group there were significant MAPCAs (major aorto-pulmonary collateral arteries) and the PAP found to be persistently high after the implantation of the conduit, one case had a ballooned Contegra postoperatively due to high PAP.

As we can see that the bovine jugular vein graft is functioning well even $11 \mathrm{yrs}$ of follow up if all variable affecting its performance were considered. 


\section{Zeid Makahleh}

\section{Conclusion}

The lack of consensus regarding the best conduit for RVOT reconstruction reflects the fact that no "perfect solution" is available. Due to its unique qualities, the Contegra ${ }^{\circledR}$ bovine valved venous xenograft offers many advantages compared to homografts and particularly compared to porcine xenografts.

It is suitable for newborns and adults. Implantation is safer and far easier for the surgeon.

During the presented 132-month follow-up, conduit function was at least as good as it was for homografts and was by far superior to porcine xenografts. We are continuing the intense follow-up to gain longterm result.

\section{References:}

1. Danielson GK, Downing TP,Schaff HV,Puga FJ, DiDonato RM, Ritter DG(1987): Replacement of obstructed extracardiac conduits autogenous tissue reconstructions. J thorac Cardiovasc Surg .,93:555559

2. Brawn WJ (1995). The use of a glutaraldehydepreserved ovine pulmonary valve as a pulmonary valve substitute in infants.Sem Thorac Cardiovasc Surg ; 7:154-156

3. Imai Y, Takanashi Y,Hoshino S, Nakatas(1995).The equine pericardial valved conduit and current strategies for pulmonary reconstruction.Sem Thorac Cardiovasc Surg;7:157161

4. Daenen W, Gewillig M (1997). Factors influencing medium-Term results of right sided cryopreserved homografts. J heart valve Dis.;6:347-54

5. Forbess JM, Shah AS, St Louis JD, Jaggers JJ, Ungerleider RM (2001). Cryopreserved homografts in the pulmonary position:determination of durability. Ann thorac Surg.;71:54-60

6. Tweddell J.S., Pelech A.N., Frommelt P.C., Mussatto K.A., Wyman J.D., Feddderly R.T., Berger S., Frommelt M.A., Lewis D.A., Freidberg D.Z., Thomas J.P., Sachdewa R., Litwin S.B(2000).
Factors affecting longevity of homograft valves used in right ventricular outflow tract reconstruction for congenital heart disease. Circulation; 102(III):130-133.

7. Bielefeld M.R., Bishop D.A., Campbell D.N., Mitchell M.B., Grover F.L., Clarke D.R (2001). Reoperative homograft right ventricular outflow tract reconstruction. Ann Thorac Surg; 71(2):482488.

8. Stark J (1998). The use of valved conduits in pediatric cardiac surgery. Pediatr Cardiol; 19:282288.

9. Lewine A.J., Miller P.A., Stumper O.S., Wright J.G., Silove E.D., DeGiovanni J.V., Sethia B., Brawn W.J(2001). Early results of right ventricular-pulmonary artery conduits in patients under 1 year of age. Eur J Cardio-thorac Surg; 19(2):122-126.

10. Homann M., Haehnel J.C., Mendler N., Paek S.U., Holper K., Meisner H., Lange R(2000). Reconstruction of the RVOT with valved biological conduits: 25 years experience with allografts and xenografts. Eur J Cardio-thorac Surg; 17:624-630.

11. Bove E.L., Byrum C.J., Thomas F.D., Kavey R.E.W., Sondheimer H.M., Blackmann M.S., Parker F.B(1983). The influence of pulmonary incompetence on ventricular function following repair of tetralogy of Fallot. J Thorac Cardiovasc Surg; 85:691-696.

12. di Carlo D., de Leval M.R., Stark J(1984). 'Fresh', antibiotic sterilized aortic homografts in extracardiac valved conduits. Long-term results. Thorac Cardiovasc Surg; 32:10-14.

13. Kay P.H., Ross D.N (1985). Fifteen years' experience with the aortic homograft: the conduit of choice for right ventricular outflow tract reconstruction. Ann Thorac Surg; 40:360-364.

14. Hawkins J.A., Bailey W.W., Dillon T., Schwartz D.C (1992). Midterm results with cryopreserved allograft valved conduits from the right ventricle to the pulmonary arteries. J Thorac Cardiovasc Surg; 104:910-916.

15. Baskett R.J., Ross D.B., Nanton M.A., Murphy D.A (1996). Factors in the early failure of cryopreserved homograft pulmonary valves in children: preserved immunogenicity? J Thorac Cardiovasc Surg; 112:1170-1179.

16. Chiu Chan K., Fyfe D.A., McKay C.A., Sade R.M., Crawford F.A (1994). Right ventricular outflow reconstruction with cryopreserved homografts in pediatric patients: intermediate-term follow-up with serial echocardiographic assessment. J Am Coll Cardiol; 24:483-489. 


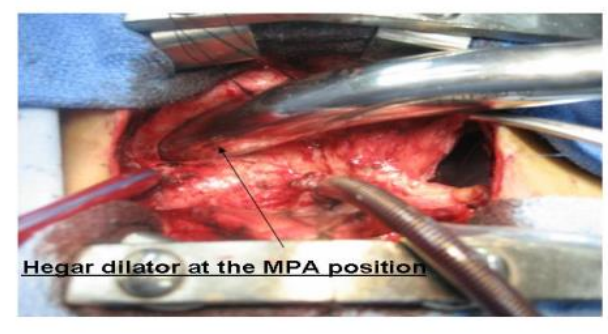

Figure1. The hegar dilator inserted at the site of main pulmonary artery to have a better idea about the final size of the valved conduit. The size of the dilator $18 \mathrm{~mm}$ and the patient's size of MPA is $16 \mathrm{~mm}$.

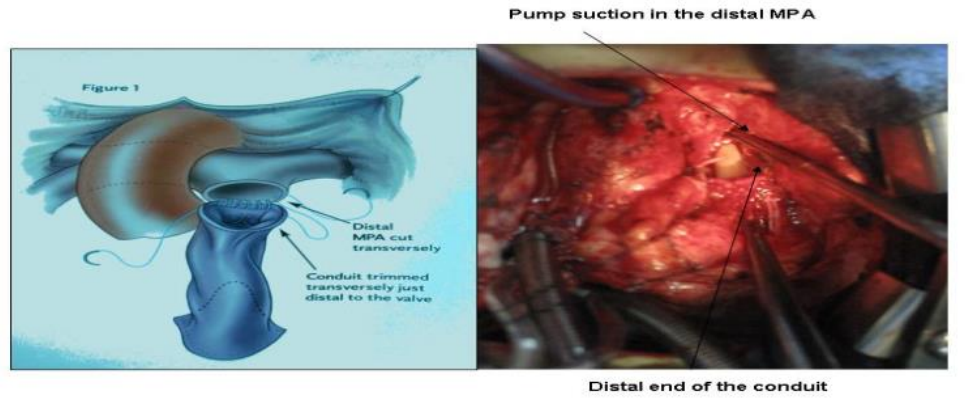

Figure2. A Contegra size $18 \mathrm{~mm}$ is anastomosed at its distal end to the main pulmonary artery in eight years old child having redo-RV to PA for previous correction of TOF (left) starting with the posterior raw and the suction in the main pulmonary artery.A. Diagram showing the same anastomosis just distal to the valve (right)
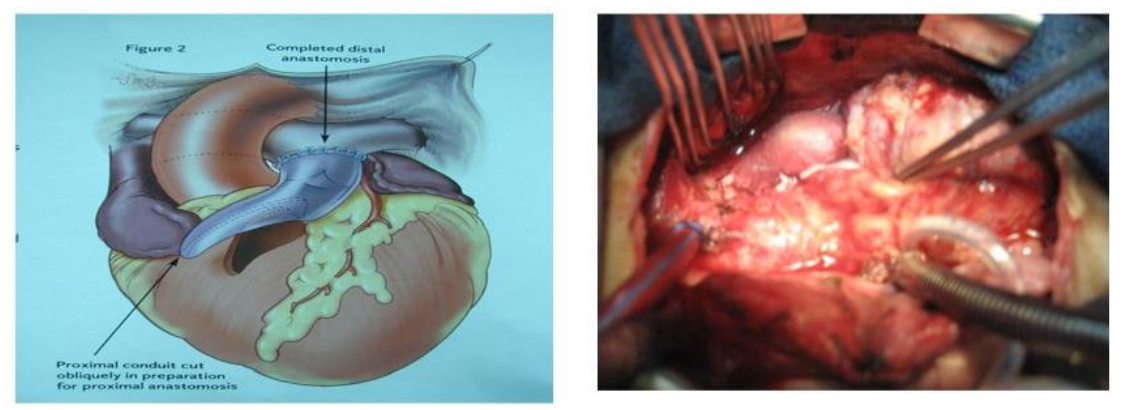

Figure 3. The final stages of connecting the proximal part of the conduit to the ventriculotomy (right). After releasing all the stay sutures and reaching the final shape (left) 


\section{Zeid Makahleh}

\section{أحد عشر عاماً من الخبرة باستخدام كونتيجرا(Contegra)}

FRCS C-Th , الاكتور زيد محمد مكاحلة

مركز الملكة علياء لأمر اض وجر احة القلب في مدينة الحسين الطبية, عمان- الأردن

كسب زرع العرق الوداجي البليديج(Contegra)- المأخوذ من الأبقار - في إصلاح العديد من عيوب القلب الخلقية (CHD) قبو لا عالميا

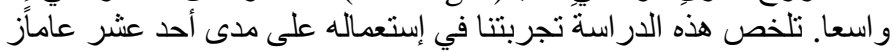
خلال الفترة من شباط/فبراير 2000-كانون الأول/ديسمبر 2011، زَرعنَا ال (Contegra) في268 مريضا بعيوبِ القلب

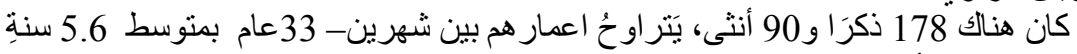
الخلقية المختلفة في موقع البطينِ-الى الثُريان الرئوي سنناقش خطو ات زراعة ال(Contegra) بين البطين الأيمن و الثريان الرئوي .

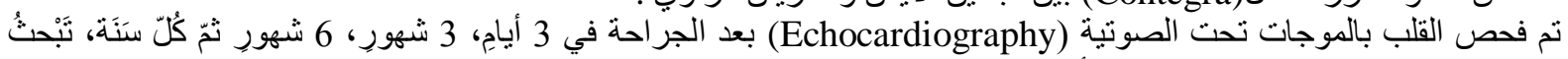

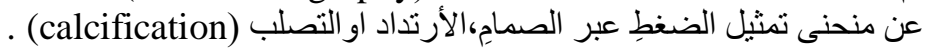

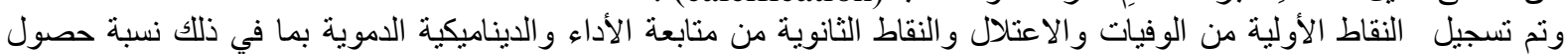

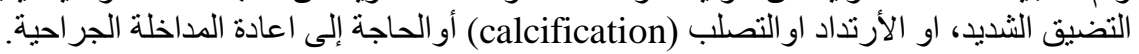

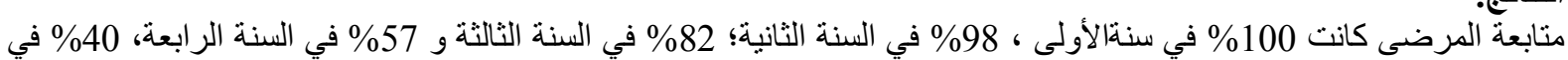

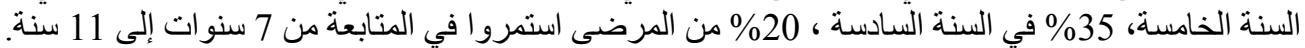

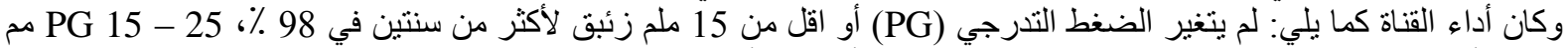

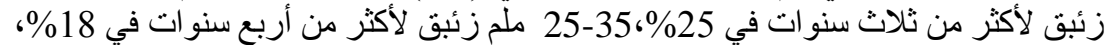

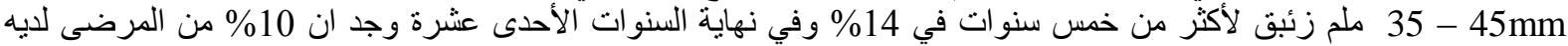

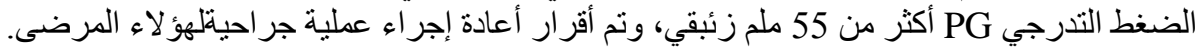

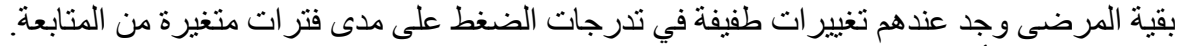

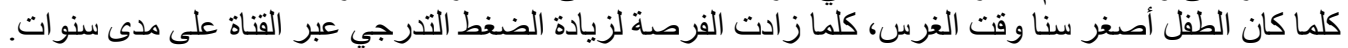
لم يكن هناك صلة للقناة بالأحداث السلبية، كان هنالك 32 حالة وفاة؛ الوفيات المبكرة 12 (4.5\%)، المتأخرة 20 حالة وفاة، ول لا لتصل أب منها بزر عناك القناة.

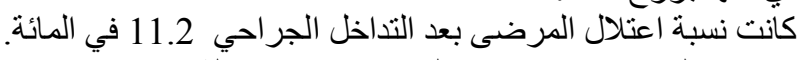

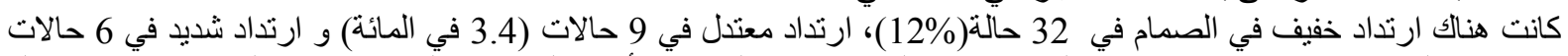
(2.2 في المائة) في فترات متغيرة من المتابعة ، تم الكثف عن تكلسات بالأشعة السينية، والكوجات فوق الصنات الصوتية في 37 حالة (13.8 في المائة) نسبة إعادة إجر اء العمليات الجر احية في 33 حالة (12.3\%) ان قنتاة كونتيجرا Contegra هي خيار موثوق ويعتمد عليها لوصل البطين الأيمن بالثريان الرئوي على مدى احد عشر عاما

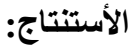

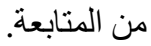

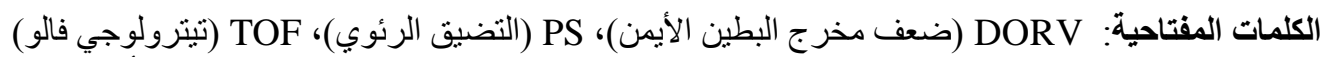

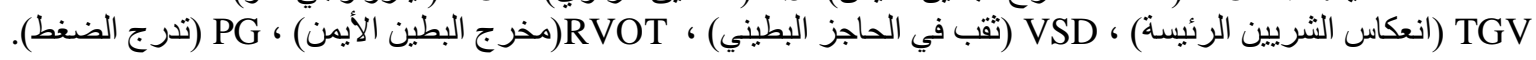

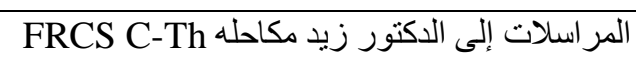

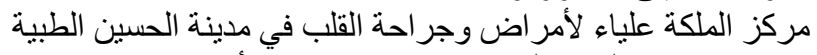

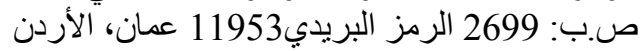
البريد الإلكتروني: zmakahleh@yahoo.com الهاتف المحمول: 200962795515001 